\title{
Are We All 'BBC Dad' Now? What Covid- 19 Restrictions Reveal About Comedy, Class, Paid Work, Parenting and Gender
}

\author{
Liz Giuffre, University of Technology Sydney
}

\begin{abstract}
The meme 'BBC Dad' first emerged in 2017 in response to an 'embarrassing' moment where a Professor was interrupted by his family during a live interview with BBC news TV. At the time the incident was circulated around the world as a curiosity, as the worlds of work, domestic (family) life and gender politics combined in a way that was apparently so unacceptable that it was comedic. The expectation was that the 'victim', the Professor, should somehow be ashamed of how his two roles as 'professional' and 'parent' had been shown to be in competition in that moment. Although this competition is often played out, especially by women and working-class workers, it is rarely shown in public, let alone discussed. However, during the global pandemic in 2020 many workers and parents are being placed in this situation and forced to juggle their dual responsibilities often in the same space and in real time. By asking 'Are we all 'BBC Dad' now?', this article questions how we consider those who conduct paid work and parent simultaneously, noting how previously accepted class and gender divides have shifted culturally as a result of the physical restraints posed by COVID-19 restrictions. The 'comedy' that the original meme provided, and the way its meaning has shifted, shows how expectations have changed and hopefully how attitudes to normally hidden workers may also shift.
\end{abstract}

Keywords

Class, comedy, gender, parenting, covid-19

\section{Introduction}

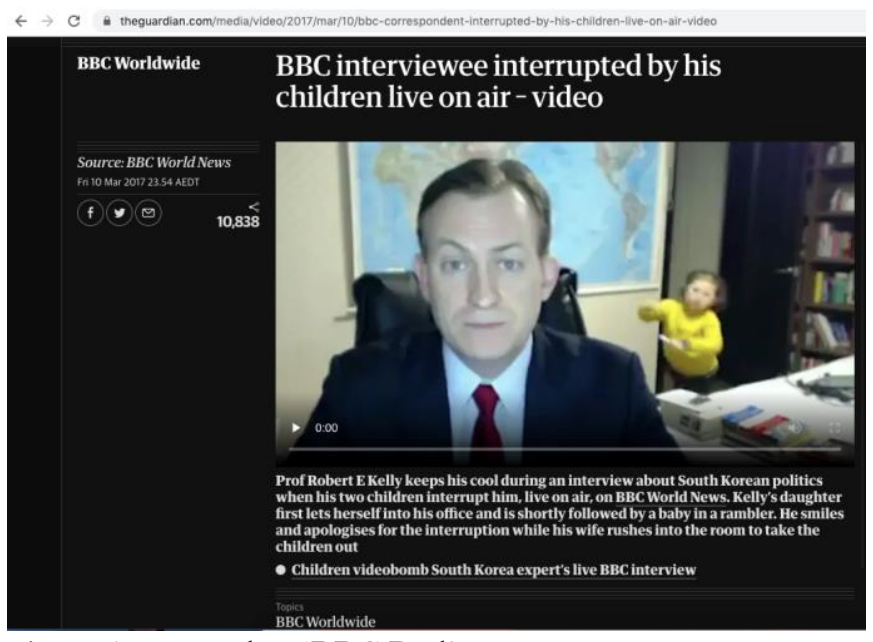

Figure 1 -screenshot 'BBC Dad' 
'BBC Dad' refers to a 2017 live BBC Worldwide television interview (BBC World News/The Guardian, 2017 - see figure 1). During the live interview Professor Robert Kelly of Pusan National University in South Korea, was talking when his children entered the room, swiftly followed by his wife who tried to usher them out without interrupting the proceedings. The children's sudden appearance in the otherwise unremarkable interview became an international meme, with their prancing young daughter and then barely-walking but smiley toddler son clearly upstaging the much more serious proceedings that the interview was meant to be covering. 'BBC Dad' soon turned into a meme to be shared and adapted rapidly online and across broadcast news outlets. From Star Wars parodies to Trump and White House reworkings (Vijaykumar 2017), it seemed the basic narrative of the meme, 'man tries to give serious talk, ends up having to admit that he has a family and that efforts to contain them are more interesting than that talk', provided perfect comedic conditions.

The 'BBC Dad' story was recirculated during global COVID-19 preventative lockdowns in 2020. The meme returned, as did interest in the continued conditions of Kelly and his family, as large numbers of workers were asked to work from their homes rather than offices. In addition, children, university and college students were also required to engage in home-based 'remote learning', creating sharp competition for domestic space. Rather than an object of ridicule, in 2020 the 'BBC Dad' began to be met with an empathy, or even, 'solidarity'. For example, on March 13, 2020 the 'one year on BBC Dad' piece was re-published on Yahoo News online with the following editorial:

'Editor's note: This [BBC Dad] story was originally published on TODAY on March 13, 2018. We're revisiting it now in solidarity with all the parents who are trying to work from home with children underfoot during this time of social distancing.' (Stump, 2020)

Professor Kelly himself has also returned to the 'BBC Dad' moment since COVID-19 restrictions were imposed. Writing again for the Lowy Institute on March 30, 2020, Professor Kelly recalled how 'my family and I briefly became famous for a blooper which became an online sensation ... The whole thing plays like a live-action comedy of errors, and it became a hit' (Kelly 2020). He continues to reflect of the incident and its impact by declaring,

'It is a weird experience becoming famous for basically doing nothing. We lost control of our kids for a few minutes. Every parent in the world does that, so we are not exceptional ... We still do not quite believe it when some random person will approach us in a restaurant or airport to ask us about the video.' (Kelly 2020)

Kelly's 2020 reflection raises an important point about the way the combination of paid work and parenting is considered. The idea that he became 'famous for basically doing nothing' raises questions about how professional work performed at home alongside parenting has come to be considered now that it has become more common and more visible as part of regular transmissions like broadcast interviews, but also private video meetings with co-workers. The 'nothing' here presumably refers to Kelly's inability to cover up his dual role as worker and parent, as he and his wife 'lost control' (or the ability to conceal) their children from the gaze of a paid workplace. Further, the suggestion that 'losing control' of kids is a mere faux pas demonstrates a class assumption that resonates differently with working-class families. In his 2020 reflection Kelly again explains how 'My blooper occurred simply because I forgot to lock my office door when I was tired late in the day' (2020). While 'being tired late in the day' is 
relatable for any worker, the idea that embarrassment might be the only consequence to this again shows a class divide.

As Attfield explains, for working-class parents the need to demonstrate an ability to produce 'respectable' children (2016) is not something that is funny, but often something that is essential. Attfield's recollection about being told to 'behave nicely when in public' by her mother "in order to not "show her up"" (2016, p. 49) suggests that an out-of-control child is not just a display of humanity, but of class and apparent ability to function in society. Attfield explains that her mother 'was very conscious of being judged, and of the need to remain inconspicuous' (Attfield 2016. p. 49), a comment relating to funding, employment and in extreme cases, protection from government interventions. Working-class parents of colour may face an even more desperate need to avoid any possible question about their ability to 'control' their children - in many places in the world communities are threatened not just with the removal of financial assistance and other practical support, but in the extreme with the removal of their children altogether. ${ }^{1}$

Importantly, when considering how work performed in the lockdown conditions of COVID19 relates to his original 'incident', Kelly writes

'a class divide over this new work mode, if it endures, is real. Workers in blue-collar and person-to-person service industries such as hairdressers or bartenders cannot telework. This is not the 'wave of the future' for a lot of people.' (Kelly 2020)

This insight is important as the issue of class was barely discussed directly in relation to the incident up until this point.

Comedy is created when basic expectations of the audience are predicted and then responded to in an exaggerated form. Ferguson sums up comedy's principles of set up and release by referencing 1970s BBC comedy icons Monty Python and their infamous 'Spanish Inquisition' sketch $^{2}$ where 'fear and surprise' were used as ways to grip the audience of the day and for the decades since $(2010$, p. 8$)$. These basic tropes have since been used in many screen comedy outputs including comedy film (Giuffre and Evans 2016, p.3), comedy television (Giuffre, 2017), and more recently comedy as it has been performed first live, and then translated into extremely binge-worthy international streaming content as with Australian comedian Hannah Gadsby's Nanette. In the latter, Gadbsy describes the mechanics of comedy as 'the artificial development of tension and release' (Gadsby 2018), a trope that has since also been used as a shorthand to understand how the politics of comedy and identity works, and upon whom power lands. At its most extreme, when gender and power have been pushed too far using these tropes, the result has been called 'anti-comedy' or 'post-comedy' (VanArendonk 2018a), as straight white middle and/or upper-class white men can no longer recognise themselves as triumphant central comedic characters as they might once have been.

\footnotetext{
${ }^{1}$ This process of the removal of children of colour is one that has happened across the world. These always accompany arguments based on class, about whether a parent is 'fit to provide' and if someone else would be more fit. Sadly, there are many examples of this, but here in Australia this process is known as the 'Stolen Generations'.

2 This sketch, from the BBC series 'Monty Python's Flying Circus', famously shows three cardinals who interrupt otherwise polite proceedings and react in a completely exaggerated and unnecessarily aggressive manner. The 'fear and surprise' reference relates both to the text of the sketch itself, but also the tools the comedians used to draw the audience in, as we are confronted by how quickly the tone of the sketch and its performances change relative to what it 'looks like' should happen. A good overview of the sketch and link to it is available via Observer (2014).
} 
The 'BBC Dad' effect, and its reliance on assumptions about surprise and fear, were different for working-class viewers. Paid work/parenting interruptions are commonplace for those who engage in shift work, casualised and unstable work, and work that is not supported by infrastructure like substantial (if any) paid parental leave or family support. Also, while a middle or upper-class worker may simply 'close the home office door' and wait for another parent or paid help to assist with parenting, for working-class families such options are beyond reach. The relationship between class and comedy, but also class and gender, will be unpacked here to show how the meme was first received, but also since the widespread COVID-19 lockdowns, how these relationships have been revisited in public.

\section{How class made 'BBC Dad' funny (the first time at least)}

By anticipating either 'fear' or 'surprise' in audience reactions, a skilled comedian can challenge stereotypes and reveal otherwise hidden truths (Ferguson 2010, p.8). The original 'BBC Dad' was not a staged comedy piece orchestrated by a skilled comedian anticipating their audience; the resulting viral reaction can also easily be summed up by 'fear and surprise': fear from middle and upper-class viewers that they might also one day be 'found out' as workers with responsibilities less prestigious than their professional working lives, and surprise from the broader international viewership that such an indiscretion should be allowed to happen at all. Working-class audiences, women and non-binary parents and carers may have also found an additional level of surprise here at the way the 'BBC Dad' reacted to the intrusion.

The 2017 clip was widely shared as a comedy of errors across social media and by broadcasters internationally as a quirky 'human interest' story at the end of news and current events programs. Featured is the part of the interview just before Kelly's children first enter the room behind him as he conducts his interview. Professor Kelly firstly ignores the children altogether. This reaction is a luxury that is only available to someone who is not their primary carer (at least during that moment in time). Professor Kelly continues his best to complete his interview while his partner attempts to coax the children out of the room. Never looking back, Kelly brushes his daughter away as she approaches him and simply closes his eyes and repeats 'I'm sorry', pausing his reply to the question until the children and his wife have left the frame. Kelly's failure to acknowledge his wife and her efforts here was also noted and was met with particular condemnation by some international commentators, with some using this as an excuse to mis-identify his wife as the children's nanny (Chok 2017).

'BBC Dad' initially generated so much international interest that Professor Kelly and his family released a press statement (Kelly 2017) and formal press conference (Bernarth 2017) to address some of the speculation about it. A year later Kelly published another formal reflection on the events (Kelly 2018) for the Lowy Institute. These revealed relatively silly internet-like conspiracy theories 'that we somehow staged the scene to become famous, and that I did not stand up because I was not wearing pants' (Kelly 2018), and showed a continued expectation that the professional middle- or upper-class working man should keep a clear distance between his domestic and professional lives. The difference between a serious mistake and comedy event is again 'fear' and 'surprise' - the fear of loss of professional reputation and surprise that perhaps this could even happen at all. In this case Kelly was 'lucky' enough to escape with mild international embarrassment rather than the loss of his job, although the threat of the latter is what had audiences laughing along. 
Performing paid work while parenting has long been a simple fact of life for working-class people. Consider, for example, the cleaners who bring their children to jobs or truck drivers who take their children on the road. However, middle- and upper-class crossovers for working parents have traditionally been shielded from public view or treated as novel. For example, the American 'take our daughters to work day' (later also 'take our daughters or sons') tradition began in the 1990s as part of a quest to get women back into the workforce after they had children (Waxman 2017). Although it is not a tradition that has been taken up beyond the USA in any easily measurable way, 'take your child to work day' has often been used in sitcoms as an easy comedic juxtaposition - as the 'professional worker' is shown to have (usually his) authority challenged in the office as his child's presence becomes something other than just an image in a frame on his desk. ${ }^{3}$

Working-class families and experiences are rarely the focus for sitcoms produced in the US, Britain and other English-speaking centres. Within these there are even fewer instances of unpaid parenting/domestic work and paid work been shown. One exception is Roseanne (19881997) where The Connors' children were shown to be involved in Roseanne's at-home telemarking job, often hanging up on clients or interrupting her as she tries to conduct her work while using the home phone in the middle of the kitchen. Beyond the scope of this article is a broader discussion about working-class life, work and parenting. There have been few working-class sitcoms created anyway, and what has been made has explored broader intersections of gender and race as well as family life. For a starting point on the complexities of these relationships see VanArendonk (2018b).

\section{How gender made 'BBC Dad' funny (the first time at least)}

The 'BBC Dad' meme and its gendered comedic reception becomes most clear when key elements of the original incident are reversed. For example, when Ellen DeGeneres discussed the meme on her daytime talk show Ellen (2017) she used a mock teacher's ruler to draw attention to its key (gendered) components and demonstrated how it functioned as comedy. DeGeneres described Kelly's daughter as having 'her own woman's march' while interrupting her father's serious debate; also noting that Kelly's wife's pants were unbuttoned as she appeared. Here DeGeneres shifted the surprise to fear for a new audience, as her own largely stay-at-home domestic audience was asked to empathise with Kelly's wife - a parent who was also interrupted while at 'work' during the interview. As DeGeneres puts it, 'the Dad was like 'I need five minutes, this is a very important interview', and the poor Mom was doing great until she had to go to the bathroom. And that's when the kids made a break for it' (DeGeneres, 2017 - see Fig. 2)

\footnotetext{
${ }^{3}$ There are many series who have featured a 'bring your child to work day' episode or incident, but some of the most mainstream examples include The Office (US), Arrested Development, 30 Rock, The Simpsons and The Big Bang Theory. For more on the history of this movement see (Wilson in Waxman 2017)
} 


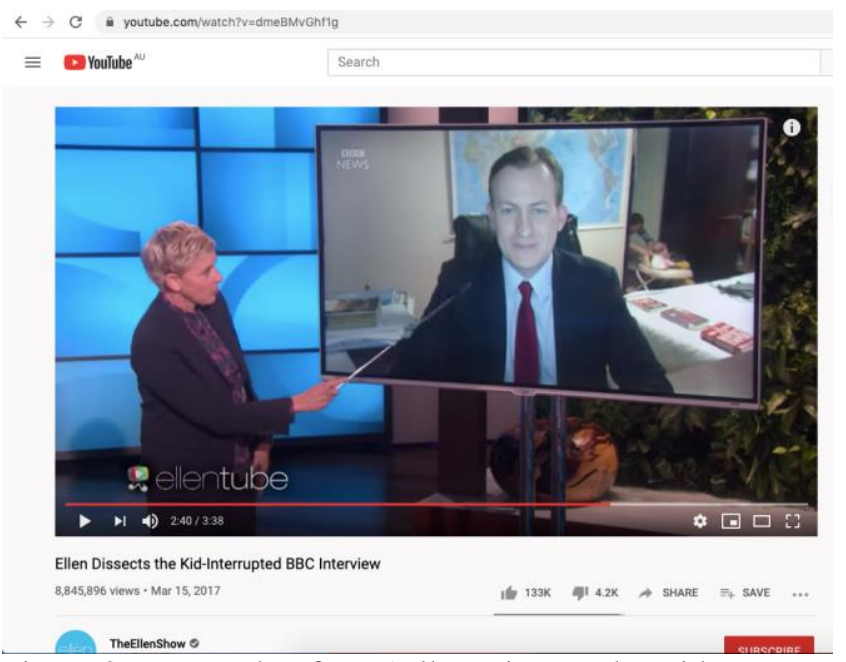

Figure 2 - screenshot from 'Ellen Dissects the Kid-Interrupted BBC Video'

DeGeneres declared the clip to be something that 'people with kids could relate to', and also would 'remind people who don't have kids why they don't' (DeGeneres, 2017). DeGeneres' focus on Kelly's wife and daughter was one of the few commentaries to explore the incident from a gendered perspective, seeing his wife as more than a prop that compounded the businessman's potential 'failure'. It also demonstrated the pressure of motherhood in conditions where paid work and parenting occur in the same space, except that her 'work' of attending to her own body is completely overlooked. Obviously, DeGeneres' comment about the choice to have children (or not), and then how to parent them, also makes assumptions about access to healthcare, education and support - access that wildly varies according to class, but also race and place. ${ }^{4}$ However, DeGeneres' willingness to focus on Kelly's wife in any detail at all as part of this incident already showed more nuance than any other reporting of the issue.

The gender 'gap' in terms of parenting/paid work responsibility and response had been noted in the 2017 original 'BBC Dad' reactions too. Perhaps one of the most biting (and entertaining) was a clip by comedians Jono and Ben (2017). Called 'Woman interrupted during BBC interview' (see Figure 3), the set-up is the same as the original 'BBC Dad', with a professional doing an interview from home. When the interview is interrupted by small children, rather than having a partner come to retrieve them or the interviewee ignore the interruption, the female interviewee takes the first child and brings it into her arms and hands the second a bottle. As the interview continues she answers more questions while cooking a roast dinner under the desk, steaming a work shirt, cleaning a toilet and defusing a bomb. The last of these serves as a perfect comedic metaphor - as, under pressure, she is called to make quick decisions about a variety of things without support. The sketch's premise, which suggests a 'BBC Mum' would face interruptions of paid domestic work on a regular basis, shows that crossovers between paid and unpaid work in the home are, for a woman, not accidents but regular occurrences that need to be factored into the workings of the day (all puns intended). Such pressures are not news to working women, or increasingly to the academy (see for example Young 2018). The only interruption she actually ignores is a man (presumably her partner) who comes in asking for help finding a missing sock - something she promises to do once the interview is completed.

\footnotetext{
${ }^{4}$ Parenting and its relationship to class has been widely written about, but for an excellent account in relation to working-class experiences see Jensen (2012).
} 


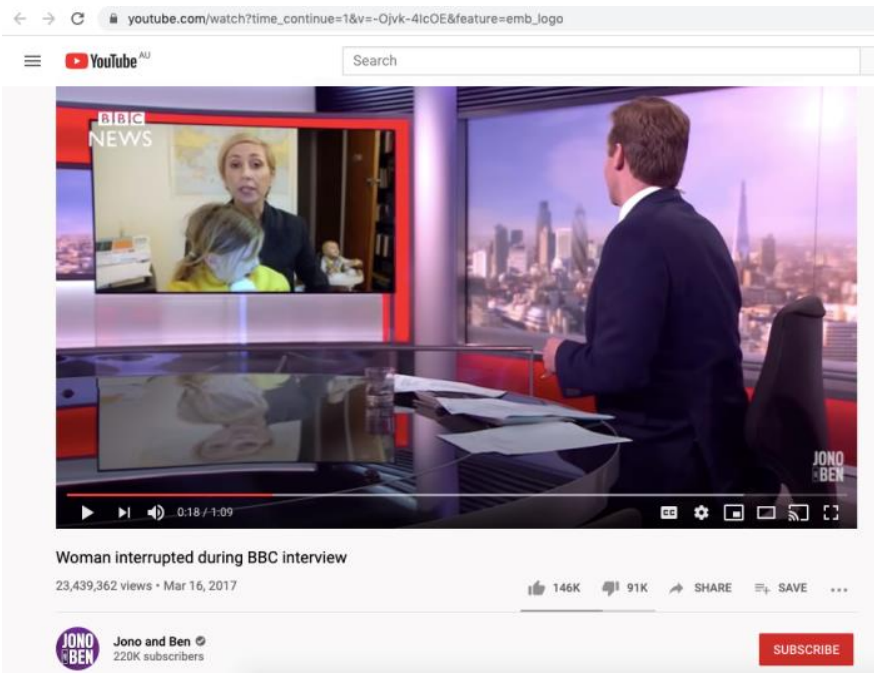

Figure 3: Screen shot from 'Woman interrupted during BBC interview'

During this parody there is no embarrassment shown, at least not on the part of the interviewee. The interviewer appears at first flustered; then impressed and finally perhaps a bit sheepish to have taken so much time out of her day. In the original (real) interview the 'working from home Dad' tries to ignore his parenting responsibilities and is visibly embarrassed to be interrupted by his children while working. In contrast, in the 'working at home Mum' parody, the woman interviewee is interrupted so often she is not only unsurprised, but swiftly prepared.

The comedy in this piece comes from the way paid and domestic work (particularly parenting) is handled when it is a woman who is being interviewed as an expert by the BBC and 'interrupted' by the needs of her children - drawing on an audience expectation of gender, too. Unlike the 'fear' of the businessman having his professionalism challenged, here the comedy comes from exaggerated surprise - on the part of the audience, not of the interviewee; there seems literally nothing the working mother cannot handle.

\section{Is 'BBC Dad's embarrassment now 'Tonight Show Dad's triumph?}

A ghost of the 'BBC Dad' meme remained in the fascinated way the media showed men performing 'dual duties' during the 2020 COVID-19 lockdown. For example, American tonight show host and comedian Jimmy Fallon regularly broadcast The Tonight Show from his house during lockdown, with his young daughters often featured as Fallon as his family worked and lived in the one space. To begin, the small girls made signs for the show's segments and played piano as 'theme music'. However, their appearances soon became regular comedy 'bits' for the at-home broadcasts. During the first 'at home' episode Fallon explained that the broadcast was to be an 'experiment', with his wife Nancy serving as the sole camera operator and the children coming in and out of shot. In the subsequent episodes the children were literally crawling all over him as he tried to maintain his composure (and Nancy Fallon, herself a high-end screen industry producer) appeared to laugh and shake the camera. (Fallon 2020a see Fig. 4). 

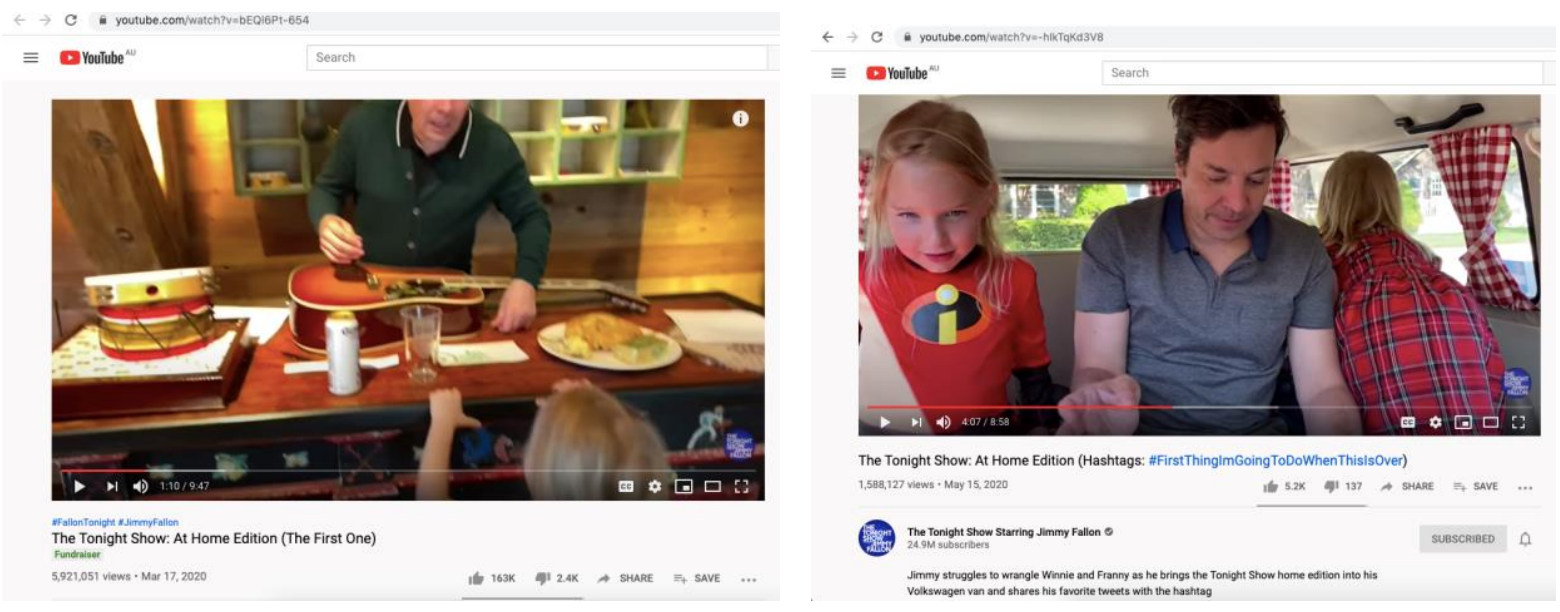

Fig 4 (left) - screen shot from 'The Tonight Show: At Home Edition (the first one)' Fig 5 (right) - screen shot from 'The Tonight Show: At Home Edition (Hashtags: \#FirstThingImGoingToDoWhenThisIsOver)'

By mid-May 2020, two months after the show's 'at home' debut, Fallon interacting with his children (or trying to 'work' and 'parent' at the same time) was clearly considered to be an important draw of The Tonight Show: At Home Edition series. For example, the description for the May 152020 segment online reads 'Jimmy struggles to wrangle Winnie and Franny as he brings the Tonight Show home edition into his Volkswagen van and shares his favourite tweets with the hashtag' (Fallon 2020b - see Fig. 5). Unlike the 'BBC (working) Dad', here Fallon was framed as a modern media hero rather than an embarrassment, shown to be a tolerant professional worker with a family, rather than someone who needed to deny their existence.

During the - initially - few nights, and then weeks, the children became obviously invited parts of the frame rather than intrusions, often upstaging him by literally drowning out his dialogue or providing more endearing 'comedic relief' to the day's events than his pre-planned scripted pieces. Their active dismissal of him too - often shown laughing or booing him - became part of the 'schtick' of the show. The children's formal inclusion in The Tonight Show was confirmed a few weeks into the 'at home' broadcasts when NBC finally updated the (apparently) home-made title cards and themes to include the children and Fallon's wife Nancy as part of the show's cast.

Unlike the original 'BBC Dad', Fallon's choice to include his children in these segments was deliberate. This showed a different kind of comedy at play - one where fear and surprise came from beyond the situation itself of 'professional worker meets domestic life'. There is perhaps some audience surprise to begin, as we are invited to empathise with Fallon who, like us, is finding combining parenthood and paid work a challenge while all are housebound. However, this doesn't quite stand up in terms of physical space, as clearly Fallon and his wife live in a very large house with lots of room for the family to distance from each other. There is little question that Fallon would need to set up his work computer on the kitchen table! What is challenged here is the idea of Fallon as an apparent 'nice guy' - as at times he seemed to be more and more demoralised by his children's constant undermining of his authority. The children also challenge the idea that the host should be the main regular drawcard of the show, as their reactions are often much funnier than his actual monologues (see Bradley 2020).

Interestingly, the prominent American late show hosts also broadcast from home with involvement from their families. None used the children as comedic subjects in the same 
blatant way as Fallon, however. Jimmy Kimmel's equivalent 'lockdown' show, Jimmy Kimmel Live (From His House), made regular reference to his small children but rarely featured them on screen (aside from using a recording of them for his theme tune), while Stephen Colbert's lockdown adaptation, A Late Show with Stephen Colbert, drafted his now young adult children to be part of his nightly production crew. Colbert often talks about or to his children but always while they are off camera, using them as only mild props rather than strong parts of his comedy set-up like Fallon. James Corden, who regularly features his elderly parents on his show The Late Late Show (and now The Late Late Show From his Garage), barely discusses his young family at all. His 'home broadcast' appears to be from his garage, suggesting he is able to 'go to work and close the door' in a way that others living in more closed quarters could not. It also implies there is someone else to look after the children while he does this. These extra carers are never discussed - perhaps for privacy reasons (which is perfectly understandable) ${ }^{5}$ - but it also shows a class divide: Corden is not pretending for a minute that he is doing dual work in the same way the others are.

The 'Tonight Show Dad' (and its equivalents) might seem to assume a 'classless' type of identity at first. Fallon's presentation in casual clothes rather than his usual suit and tie already blurs the line between paid work and something else - the 'experiment' of providing entertainment rather than creating a broadcast show for a profession. However, the host and his guests give themselves away when they talk to the camera 'from home' inevitably showing their domestic spaces to be wealthy spaces - always furnished well, often in different locations within the house and its surrounds. This breaks any illusions to the crowded house or 'comedy of errors' that was implied with the original 'BBC Dad', and it also challenges the notion that these celebrities present a type of 'relatability' during this time. While yes, they might be talking to the camera, and the audience, from their homes and without their normal support networks, the experience of doing so from a multi-million dollar mansion away from a crowded COVID-19 riddled city is very different to the experience of audience members who may be watching in cramped, working-class conditions. It could be said that here another layer of comedic appeal is created - as working-class audiences witness the wealth displayed by these talk show hosts who, despite this, are still not coping with lockdown. In this instance, surprise comes as people who were once considered successful, by virtue of their celebrity, are now struggling to stay relevant and connected to their audiences (Wise 2020).

\section{What about a BBC Mom (Mum)?}

With the exception of Samantha Bee's weekly magazine show Full Frontal there aren't any 'Tonight Show women' with which to compare these examples. Mainstream Anglophone television has rarely featured women in these roles, a tradition which continues to this day. Notwithstanding the problems with this in itself, this limited representation of gender, as well as class and race, further sidelines motherhood and non-traditional 'Dad' parenting. An excellent discussion about what contemporary creative industries should do about this and how this needs to be addressed has been started by Dent (2020), but there is much more to be done. A locked-down version of Full Frontal was produced, starting with a home mini-series called 'Beeing at home'. These pieces showed Bee set away from the domestic space as possible, most often broadcasting from a location 'in the woods' near her house. ${ }^{6}$ The deliberate choice

\footnotetext{
${ }^{5}$ Curiously, there has been little public discussion about choices celebrities have made, or not, to show their families on camera as part of these shows. One exception is Lin-Manuel Miranda (Kahim 2020), but this opens up questions about privacy for ordinary workers as well.

${ }^{6}$ There would easily be scope for an entire article on these shows alone, but for a good round up so far see Wright (2020).
} 
to not be inside or with family in the frame demonstrates a want to build comedy as part of a different relationship. Where Bee and her team did mention children in the early episodes of this series, there was a much more direct engagement than Fallon's apparently passive 'intrusions'. For example, the Full Frontal correspondent Allana Harkin discussed the 'Angry Mom' as part of her 'Quarantine Questions' segment. Her comedic response was clearly rooted in sarcasm as she declared 'yes, Angry Mom is a routine, we've just been kept down for years and years and decades, we have nothing to say, it's all a routine' (Harkin 2020). The speech is brief but delivered with a huge smile that grows as she ends with a Stepford-Wife like pose. Clearly playing on white middle-class stereotypes, the comedic surprise here comes from the exposed ridiculousness of the question - during lockdown especially, there is easily plenty for Moms of all types to be angry about.

During the early weeks of the lockdown even high-profile women like New Zealand's Prime Minister Jacinda Ardern were shown at home with clear distinctions between paid and unpaid work. The difference between her appearance and that of the 'BBC Dad' tonight show hosts was apparent as she engaged with her citizens (and a wider audience) on social media and made a point of noting, herself, that she was 'jumping online quickly' to 'check in with everyone', saying 'excuse the casual attire ... I was putting my toddler to bed so I'm not in my work clothes, forgive me for that' (Ardern 2020 - see Fig. 6).

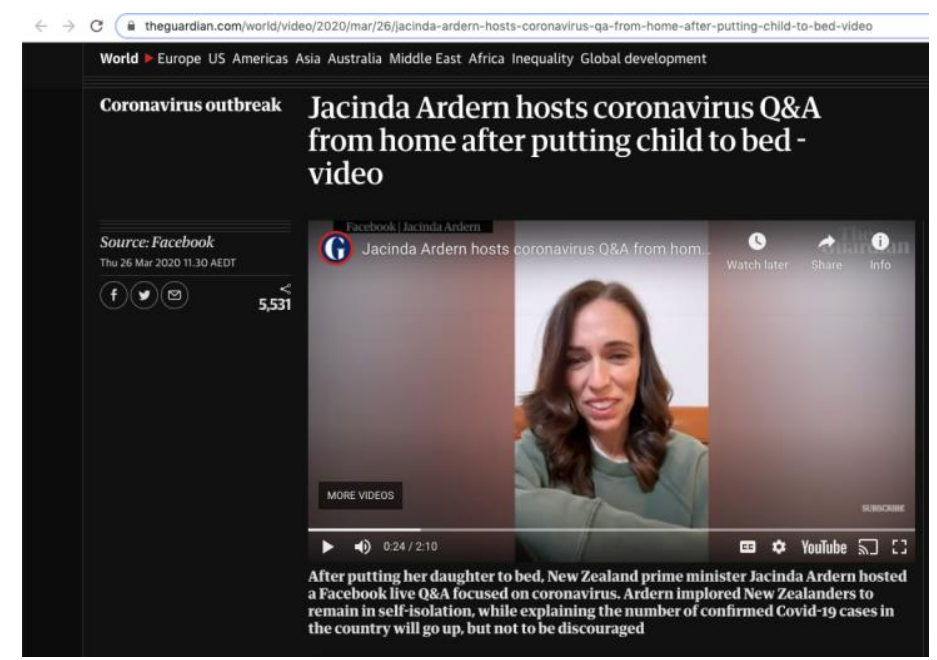

Fig 6: Screen shot of Jacinda Ardern's Facebook address.

Curiously, in its reporting of the video, news outlet The Guardian led the story by noting that Ardern had performed her parental role ('putting her daughter to bed') ahead of discussing the content of her address to the nation she leads. Similar frustrations were vented, and their consequences noted, in academia. Minello wrote a much-circulated commentary for the journal Nature, arguing 'data on publication records over the next couple of years will show that parents in academia were disadvantaged relative to non-parents in 2020' (Minello 2020). Going further to push this divide along gender lines, she added 'Care work is, in fact, unbalanced - even among highly educated couples' (Minello 2020). Although Ardern's much-publicised partner is a primary care giver for their daughter, here, again, Ardern is framed as a parent and paid worker, rather than allowed to be just the latter.

Minello also turns to humour to explain, or perhaps cope, with current events. She cites commentary from social media about the relationship between paid work, parenting and gender, saying, 
Humour is one way for women in academia to face the pandemic's consequences for their work and family lives. Last month, a viral Twitter post read, 'The next person who tweets about how productive Isaac Newton was while working from home gets my three year old posted to them!' (Minello 2020).

In Australia journalist Annabel Crabb also referenced the 'Issac Newtown tweet', adding support from an evolving study by researchers at the University of Melbourne which has preliminarily shown that women during lockdown have continued to work and parent from home in disproportioned numbers to men (2020). She sums up the effects of COVID-19 restrictions on movement of workers and children by citing a 'pink collar recession' in the making, concluding that, 'Women right now are more likely to lose work that is paid and also more likely to pick up work that is unpaid' (Crabb 2020). To answer the question 'what about the 2020 BBC Mum?', Crabb's findings might say 'she's likely to soon be unemployed.'

Class returns as a particular issue here, however, given that in the COVID-19 environment discussion of 'essential workers' - workers previously given little respect - are now being given a spotlight. In particular, cleaners, delivery workers, nurses, transport workers - often all those considered as part of the working class - are being acknowledged as performing duties that otherwise locked down or 'on hold' cities cannot function without. However, these are also jobs that cannot be done at home. The 'BBC Dad' problem, or the idea of simultaneously performing paid work and parenting at home, hits these workers even harder. How can a hospital cleaner look after their own child at home if they must leave to go to work outside that home? And perhaps, to do so with more overtime now as demand is greater for their services (and, of course, the danger of doing so is also significantly higher)?

Wilson's emphasis on 'going out to work' is framed by the cost she says she paid for the practice. Just before this quote above, Wilson adds, 'I didn't have time to give my children the time they needed, particularly once I went to work. It was hard on them.' (Wilson in Waxman 2017) This last comment about the price a working mother pays when being separated from her children is one that is almost never discussed in terms of working fathers, and if it is, is still seen as a relatively new phenomenon (Larsson and Bjork 2017; Fong and Bainbridge 2016; Goldstein-Gidoni 2020). Historically, it has been part of the argument against 'working parents' (particularly working mothers) - an argument that has always been based in class. The idea of having a 'choice' to work is one that working-class people of both genders often do not have in practice. Both or any member of the household that can work often need to in order to contribute to the family - including children when they are old enough. As has been well documented, these class issues are also further compounded by race, as the idea that migrant women or women of colour could simply 'choose not to work' is a myth; instead they are overwhelmingly employed illegally or chronically underpaid/paid in kind. ${ }^{7}$

\section{Are we all now (and maybe forever) 'BBC Dad'?}

I revisit the 'comedy' of the original 'BBC Dad' piece in 2020 carefully, very mindful not to undermine or downplay the severity of the situation that is unfolding as a result of COVID-19. However, by looking at the power relationships that comedy highlights, and how these have changed, we can see how the pandemic has challenged cultural expectations about gender and class (at least in some places). The 'BBC Dad' or 'Tonight Show Dad' tropes also cover up

\footnotetext{
${ }^{7}$ There is a wide literature covering these issues, but one of many good starting points is the edited collection by Russo and Linkon (2005).
} 
those workers and situations who have more to lose in terms of cultural and literal capital. Middle- and upper-class women in paid work are still at risk of having their contributions as 'professionals' overshadowed by their work as 'mothers', while working-class people in high demand (and high risk) jobs are not given the opportunity to choose at all - they are required to leave their houses, and their parental responsibilities - with higher stakes than ever before for what seems like no recognition at all. Women and working-class people are overlooked in the original memes, and again in its replacement with the 'Tonight Show Dad'. This shows that, still, their power and place performing dual duties - in the paid workforces and as parents also - is still taken for granted.

Of course, all of this is dependent on specific gender and class expectations and contexts. Choice is dependent on having the luxury of other options. In some cases this means a luxury of literal space - middle- and upper-class workers are much more likely to have somewhere they can dedicate to work when compared with working-class people and their families. If you have an office door to close, then 'forgetting' to close it becomes comedy like the BBC Dad; but if your office is the end of the kitchen table or side of a shared bedroom, these intrusions are less about surprise and fear are more inevitable and frustrating. If your work is in the street, on the road or in a cleaner's cupboard, you have no choice at all. The very real threats of mental health trauma, domestic violence and other forms of harm that may occur during these periods of isolation are also of huge concern, and much more dangerous than the potential loss of reputation that the original BBC Dad threat posed.

\section{Coda - A personal note.}

I agonised about whether or not to add this, but here it is.

This article was written during lockdown. My husband and I both work full time, and we have a baby and a toddler in a two-bedroom rented apartment. I add this because it seems ironic to leave out this detail, showing my own proximity to the 'BBC Dad/Mum' type. I wonder at what other time would I need to disclose this aspect of my personal life as part of my professional one? I am also very aware of how my position as a now middle-class worker (an academic) provides me with some ability to at least pretend that my unpaid domestic work has not intruded into my paid professional work as much as it has during this time. Many of my working-class colleagues, overwhelmingly 'frontline workers' in female-dominated areas like nursing, cleaning and caring roles, have not had this option.

However, I have decided to include this coda as a thank you - without the support of this journal (my co-editor Sarah Attfield and blind peer reviewers with very flexible timelines), as well as additional assistance from proofer/editor Demetrius Romeo, it would simply not be possible for me to do 'both jobs'. Important acknowledgement of the team effort made by my husband and I is also needed here too. However, I do wonder how many of my male colleagues would feel the need to issue a similar thankyou/disclosure, even though they have likely also benefited from help from the 'village' in order to have them perform their dual duties?

\section{Author Bio}

Liz Giuffre is a Senior Lecturer in Communication for the Faculty of Arts and Social Sciences. In addition to this she works regularly in the national independent arts press as a journalist and commentator, including work as the regular contributing editor for Metro Magazine, a regular contributor to Critical Studies in Television, reviewer and interview for The Music and 
occasional contributor for The Conversation. She is an associate member of the Centre for Media History, and the former publication/web officer for IASPM Australia/New Zealand. With Dr Sarah Attfield, she is also the co-founding editor of the Journal of Working-Class Studies.

\section{Bibliography}

Ardern, J. 2020, 'Q and A from home via Facebook', The Guardian, 26 March 2020, viewed 21 May 2020, <https://www.theguardian.com/world/video/2020/mar/26/jacinda-ardern-hostscoronavirus-qa-from-home-after-putting-child-to-bed-video $>$.

Attfield, S. 2016, 'Rejecting respectability: on being unapologetically working class', Journal of Working-Class Studies, vol.1, no.1, pp. 45-57.

BBC, 2020, 'Labour's Jonathan Ashworth experiences BBC Dad moment', BBC online, 11 April 2020, viewed 21 May 2020,

<https://www.bbc.com/news/av/uk-52257672/labour-s-jonathan-ashworthexperiences-bbc-dadmoment?at_custom3=BBC+Family+\%26+Education+News\&at_custom $1=\% 5$ Bpost + type\%5D\&at_campaign $=64 \&$ at_medium $=$ custom $7 \&$ at_custom $4=C D C B A 84 A-$ 7D5A-11EA-8A3860A8FCA12A29\&at_custom2=facebook_page\&fbclid=IwAR3PLn61xflgWgpRUI7X hf9cHDo2fg8Fe0bkEROM0OFWyZnpzv8g7c8RSjM>.

BBC World News/The Guardian, 2017, 'BBC interviewee interrupted by his children live on air - video', The Guardian 10 March 2017, viewed 21 May 2020, $<$ https://www.theguardian.com/media/video/2017/mar/10/bbc-correspondentinterrupted-by-his-children-live-on-air-video>.

Bernarth, B. 2017, 'BBC Dad's cute kids steal the show once again during press conference', Today.com, 17 March 2017, viewed 21 May 2020,

$<$ https://www.today.com/parents/bbc-dad-s-cute-kids-steal-show-once-again-during$\mathrm{t} 109294>$.

Bradley, B. 2020, 'Jimmy Fallon's daughters completely take over their Dad's interview', The Huffington Post, May 14 2020, viewed 25 May 2020

$<$ https://www.huffingtonpost.com.au/entry/jimmy-fallons-daughters-completely-takeover-their-dadsinterview_au_5ebc61a5c5b6cdefa7e8f934?guccounter=1\&guce_referrer=aHR0cHM6 Ly93d3cuZ29vZ2xlLmNvbS8\&guce referrer_sig=AQAAALn2DE38ANyJJP7PNJNAedX3H6Cmdo-nCjkgUPW07gZDBAsMC96MYS9AjXmlJ8aBfXolkkLhtJU6bHcwg_iXCnX4SlwajNgpbZBMNpAM_iDcGgYUP97kVt8bqO3ipiyEvTG2t3Qx-yxzcViQ5HLOBZZWz57jR1UZJe46Jy0K4>.

Chok, V. 2017, 'If you saw a nanny in this BBC interview, what does that say about you?', The Guardian, 14 March 2017, viewed 21 May 2020, $<$ https://www.theguardian.com/commentisfree/2017/mar/13/nanny-bbc-interviewrobert-kelly-small-children>.

Crabb, A. 2020, 'Coronavirus has left Australian women anxious, overworked, insecure - and worse off than men again', $A B C$ Online, 24 May 2020, viewed 26 May 2020, <https://www.abc.net.au/news/2020-05-24/coronavirus-has-set-back-progress-forwomen-workplace-equality/12268742>.

DeGeneres, E. 2017, 'Ellen dissects the kid-interrupted BBC Interview', The Ellen Show (YouTube Channel), 17 March 2017, viewed 21 May 2020, 
$\langle$ https://www.youtube.com/watch?v=dmeBMvGhf1g $>$.

Dent, T. 2020, 'Devalued women, valued men: motherhood, class and neoliberal feminism in the creative media industries', Media, Culture and Society, vol. 42, no.4, pp 537-553.

Fallon, J. 2020a, 'The Tonight Show: At Home Edition (The First One)', The Tonight Show, (YouTube Channel), 17 March 2020, viewed 21 May 2020, <https://www.youtube.com/watch?v=bEQ16Pt-654>.

Fallon, J. 2020b, 'The Tonight Show: At Home Edition (Hashtags: \#FirstThingImGoingToDoWhenThisIsOver)', The Tonight Show (YouTube Channel), 15 May 2020, viewed 21 May 2020, <https://www.youtube.com/watch?v=-hIkTqKd3V8>.

Ferguson, T. 2010, The cheeky monkey: writing narrative comedy, Currency Press, Melbourne. Fong, M. M., Bainbridge, H. T. J., 2016), 'Working fathers: determinants of time allocation to work and family roles', Labour \& Industry: a Journal of the Social and Economic Relations of Work, vol. 26, no.3, pp. 203-219.

Gadsby, H. 2018, 'Nanette', Netflix Australia, <https://www.netflix.com/au/title/80233611>.

Giuffre, L., Evans, M. 2016, 'Sounding Funny: the importance of hearing (as well as seeing) the joke' in M. Evans \& P. Hayward (eds.), Sounding funny - sound and comedy cinema, Equinox eBooks Publishing, United Kingdom, pp. 1-13.

Giuffre, Liz, 2017, 'Introduction" in L. Giuffre \& P. Hayward (eds,), Music in comedy television: notes on laughs, Routledge, New York and London, pp. 1-14.

Goldstein-Gidoni, O. 2020, ' Working fathers in Japan: Leading a change in gender relations?', Gender, Work and Organisation, vol. 27, no.3, pp 362-378.

Harkin, A. 2020, 'Quarantine questions: Addressing the 'Angry Mom' Routine: Full Frontal on TBS', Full Frontal with Samantha Bee, (YouTube Channel), 19 May 2020, viewed 1 June 2020, <https://www.youtube.com/watch?v=mLP769fzWl0>.

Jensen, B. 2012, Reading classes: On culture and classism in America, Cornell University Press, New York.

Jono and Ben, 2017, 'Woman interrupted during BBC interview', Jono and Ben (YouTube Channel), 16 March 2017, viewed 21 May 2020,

$<$ https://www.youtube.com/watch?time_continue=1\&v=-Ojvk4IcOE\&feature=emb_logo $>$.

Kamin, D. 2020, 'Working from home, celebrities grapple with revealing too much', New York Times, 4 May 2020, viewed 21 May 2020,

<https://www.nytimes.com/2020/05/04/realestate/working-from-home-celebritiesprivacy-coronavirus.html>.

Kelly, R. E, 2020, 'BBC Dad has learned a thing or two about working from home', The Interpreter/The Lowy Institute, 30 March 2020, viewed 21 May 2020, <https://www.lowyinstitute.org/the-interpreter/bbc-dad-has-learned-thing-two-aboutworking-home>.

---. $\quad 2018$, 'A year of internet stardom: 'BBC Dad' reflects', The Interpreter/The Lowy Institute, 11 March 2018, viewed 21 May 2020, <https://www.lowyinstitute.org/theinterpreter/year-internet-stardom--bbc-dad-reflects $>$.

---. $\quad 2017$, 'Kelly family press release on the 'BBC Dad' viral video', Robert Kelly - Asian Security Blog: International Relations of Asia \& US Foreign Policy, 15 March 2017, viewed 21 May 2020, <https://asiansecurityblog.wordpress.com/2017/03/15/kellyfamily-press-release-on-the-bbc-dad-viral-video/>.

Larsson, J., Björk, S. 2017, 'Swedish fathers choosing part-time work', Community, Work \& Family, vol. 20, no.2, pp.142-161.

Minello, A. 2020, 'The pandemic and the female academic', Nature 17 April 2020, viewed 21 May 2020, <https://www.nature.com/articles/d41586-020-01135-9>. 
Observer 2014, 'Monty Python's greatest skits', The Observer, 22 June 2014, viewed 21 May 2020, <https://www.theguardian.com/culture/2014/jun/22/monty-pythons-greatestskits-best-sketches-o2-shows $>$.

Russo, J., Linkon, S. (eds.) 2005, New working-class studies, Cornell University Press, Ithica. Stump, S. 2020, 'BBC Dad' reflects on viral work-from-home moment: 'Mostly fun, sometimes weird', Yahoo News, March 18 2020, viewed 21 May 2020, <https://news.yahoo.com/bbc-dad-reflects-viral-home-183633204.html>.

VanArendonk, K. 2018a, '8 signs you're watching a post-comedy comedy', Vulture, 5 September 2018, viewed 21 May 2020, <https://www.vulture.com/2018/09/postcomedy-taxonomy.html>.

---. $\quad$ 2018b, 'A timeline of TV's working-class sitcoms', Vulture, 18 May 2018, viewed 21 May 2020, <https://www.vulture.com/2018/05/working-class-sitcoms-timeline.html>.

Vijaykumar, N. 2017, 'One week into it, BBC Dad sparks off more viral memes', The Week, 17 March 2017, viewed 21 May 2020, <https://www.theweek.in/webworld/features/society/bbc-dad-robert-kelly-viralmeme-crashing-into-interview.html >.

Waxman, O. 2017, 'The inside story of why take your daughter to work day exists', Time Magazine, 26 April 2017, viewed 21 May 2020, <https://time.com/4753128/take-yourour-daughters-to-work-day-history/>.

Wise, L. 2020, 'There's a sense that celebrities are irrelevant': has coronavirus shattered our fame obsession?' The Guardian, 2 May 2020, viewed 25 May 2020, <https://www.theguardian.com/culture/2020/may/02/theres-a-sense-that-celebritiesare-irrelevant-has-coronavirus-shattered-our-fame-obsession>.

Wright, M. 2020, 'How the late-night shows are handling coronavirus quarantine', Vulture, 8 April 2020, viewed 21 May 2020, <https://www.vulture.com/2020/04/late-nightshows-nyc-coronavirus.html>.

Young, Z. 2018, Women's work: how mothers manage flexible working in careers and family ife, Bristol University Press, Bristol. 